\section{New brooms plan clean sweep}

\section{Ottawa}

CANADA's science chiefs are expecting great things from their new progressive conservative minister, Thomas Siddon. With a professional engineering background and a PhD in aero-acoustics, Siddon is highly spoken of as a friend of science and may be the man to gain some much-needed political clout for his office as minister of state for science and technology.

One of the first signs of renewed emphasis on science may be the creation of a standing parliamentary committee to deal with technology development. And by all accounts the recent Wright Task Force report urging more demand-led research and development (see below) is being taken very seriously. While some science administrators admit to private doubts about the numbers, Siddon intends to deliver his party's pledge to double Canadian research and development to C $\$ 10,600$ million within its first term of office.

Most of this increase needs to take place within industry. Canada suffers from being a "branch plant" economy - many companies based in the United States use Canada simply for warehousing and distribution - and this Siddon is determined to change. The activities of major companies will be examined and government investment and tax measures deployed to favour more innovation within the country. There is a strong feeling that trading competitors have been making gains from various forms of hidden assistance to their domestic industries, and the intention now is that Canada should use every fiscal measure permitted under the General Agreement on Tariffs and Trade to protect its home base.

One high priority is to revise the scientific research tax credits introduced earlier this year. That scheme, intended to help young high-technology companies that did not benefit from traditional tax incentives, has already proved an embarrassment: although a boon for investment dealers, it has cost the government significant revenue and has failed to generate innovation on the scale intended.

Changes can be expected at laboratories run by government departments and by the National Research Council (NRC), which cover everything from measurement standards to cancer research. A proposed manufacturing technology centre to be run by NRC was planned by Wright as representing "everything that is wrong with federal technology policy": industry was not consulted and the facility may be redundant before it is built. NRC's technology transfer programme has failed to make a real impact on Canadian industry, and Siddon wants to contract out some NRC work to make more productive use of the laboratories.

While most Canadian universities have science departments, subject cover is patchy and there is serious concern about the future supply of highly qualified manpower. Despite Siddon's obvious enthusiasm for development as opposed to research, he "can give an assurance" that federal support for university-based

\section{Looking south}

THE Canadian economy is beset with problems stemming from its historical reliance on natural resources and its poorly-developed indigenous industry: more than $\mathbf{5 0}$ per cent of manufacturing industry is foreign-owned, and the per capita budget deficit is much larger than that in the United States. Research and development accounts for only 1.28 per cent of the Gross National Product, less than half the figure in the United States, and by the latest unofficial estimates the proportion is actually decreasing.

One major difficulty is the lack of venture capital: unlike their entrepreneurial neighbours to the south, Canadians prefer to save their money than to put it at risk, and insurance is big business. Many banks refuse to make loans for commercial ventures unless the idea has previously been tried in the United States. Canada also lacks the defence-based industries of the United States.

A hard-hitting task force report released in July urged the government to stimulate private sector research by rationalizing and simplifying industrial support schemes, providing better tax incentives and redirecting government procurement policies. The task force, under the chairmanship of Douglas Wright of the University of Waterloo, said the federal government should pay the full cost of university research, thus eliminating the political dimensions of the present research support system under which indirect research costs ("overheads") are met by provincial governments. Cooperation between universities and industry should be strengthened by a flat-rate grant to universities undertaking industrial research and development by tax concessions for industrial companies making use of universities.

Wright was highly critical of Canada's federal laboratories, some of which are "struggling to find appropriate challenges". The suggested solution was that directors recruited from industry should be given authority to set goals for federal laboratories, encouraging them to contract out research as much as possible. A formal government response to Wright is in preparation.

Tim Beardsley research will be "continued and expanded". But this will require difficult negotiations with provincial governments, which, though supposed to support education, have in practice ensured a creeping increase in the unit cost of research supported by the research councils. Siddon also wants to encourage academics to follow through development of important discoveries by promoting the idea that consultative work for industry as well as peer-reviewed academic publications can advance a university career.

Much of this ambitious programme will depend on what sort of influence Siddon can wield in cabinet. There is room only for improvement: science and technology has at different times had to share a minister with other departments and there have been 10 incumbents of the office since 1971. But Siddon, who was a critic of science and technology in the last parliament, has 5 years' parliamentary experience, making him almost a veteran in the cabinet. The traditional hewers of wood and drawers of water had better watch out. Tim Beardsley

\section{Microscope acquired}

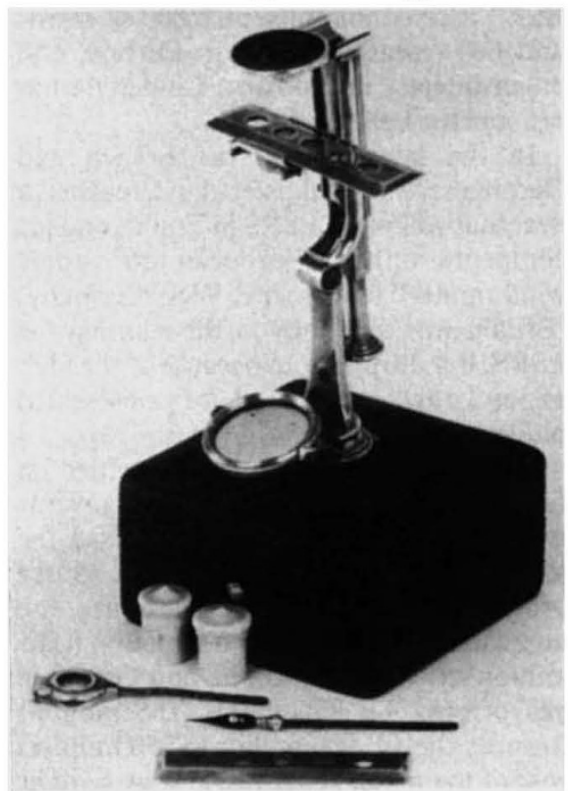

ONE of the earliest British scientific instruments to be designed, constructed and marketed outside London has just been acquired by Edinburgh's Royal Scottish Museum. The instrument, a 2-inch high silver microscope made in 1749 , was a product of the workshop of John Clark, an Edinburgh goldsmith, jeweller and instrument maker. Although its eighteenth century purchaser would have been a Scots gentleman of leisure, desiring a novel curiosity, it was nevertheless the patronage of such customers that spurred instrument makers to develop the skills they would need to meet the demands of their first scientific and medical customers. The museum was assisted in making the purchase by the National Heritage Memorial Fund. 